\title{
THE ALEXANDRIAN LIBRARY AND ITS AFTERMATH
}

\author{
By Uwe Jochum \\ University of Konstanz Library
}

The library of the Museion in Alexandria is generally regarded as the first universal library. However, a look at the few authenticated facts will show how questionable such a characterization is. The universality of the library of the Museion seems to have its roots in the stories that are told about it, most famously about its destruction. The fact that this story, as well as others, hardly stands up to close examination is to be seen rather as a peculiar characteristic than as a defect. Ever since philology emerged at the Alexandrian Library, we communicate by our history and our stories, by doing philology (or by having to do philology). Therefore the universality of the library of the Museion might be based on the fact that it has to be viewed as a library phenomenon which was preserved in the collections of many libraries. This paper was delivered at the library bistory seminar held in London in 1996 on the theme of the 'Universal Library'.

A scrutiny of some histories of the Alexandrian library suggests that it is the perfect model of a universal library because it collected every book on every subject in every language. The Alexandrian library therefore contained not only the enkyklios paideia, i.e. the circle of learning, but was a monument to a more far-reaching concept: all aspects of human knowledge, from scientific to everyday, were to be found on the shelves of the Alexandrian library. Today such an idea seems outdated. In the course of the nineteenth century, the circle of learning expanded into many worlds of learning, and ever since we have had an incoherent profusion of sciences, each of them publishing copiously. It is therefore absolutely impossible to collect the complete published scientific record, much less the whole range of what the Greeks referred to as technê, with all those books on horseback riding, driving a car, and baking. This explains why Daniel Gore declared twenty years ago that the solution to our library problems would consist in a 'Farewell to Alexandria', and in a new library as a non-growth collection of books. ${ }^{1}$ In our time, another $\mathrm{Mr}$ Gore is trying to convince us that we should be aiming for an information superhighway offering everyone free access to all documents - on condition that the documents are converted from paper to electronic format and on condition that this fabulous information superhighway is more than the daily traffic jam that it actually is.

In any event, calling to mind the Alexandrian library would appear to be a piece of old-fashioned history - entertaining if it is good, boring if it is bad, but without any relevance to what transpires in our modern or postmodern libraries. But what if the history of the Alexandrian library revealed that there is no alternative to the Alexandrian concept of a library? In this case, all our modern or postmodern attempts to get rid of 
the physis of books and libraries would be mistaken, so that the alternative to the Alexandrian library is not a better modern or postmodern library, but no library at all. Let us see whether history will take us to that point.

\section{The history}

There were two libraries in ancient Alexandria: the library in the Serapeion, the Shrine of Serapis, situated in a district of the city called Rhakotis, where most of the Egyptian inhabitants of Alexandria lived, and the library situated in the Brucheion, the palace area of Alexandria. ${ }^{2}$ When we refer to the Alexandrian library, we usually mean the latter, ${ }^{3}$ known as the 'King's library', 'the library of the Museion', or the 'great/big/large library' (depending on how one translates the Greek megalê bibliothekê ). ${ }^{4}$

It is an accepted fact that, after his expulsion from Athens, Demetrius of Phaleron, a pupil of the Aristotelian philosopher Theophrastus and for some years ruler of Athens, went to Alexandria, where he was charged by Ptolemy I with building an institution for scientific research. Since Demetrius was familiar with the Aristotelian Peripatos in Athens, and since the Peripatos had as its centre a museion, a temple of the Muses, and because an integral part of the Peripatetical museion was a library, it is also accepted that Demetrius modelled his Alexandrian institution on the Aristotelian Peripatos, building a museion with a library. And from the very beginning the word museion became the proper name of the whole Alexandrian institution: the Museion. Demetrius having been expelled from Athens in 307 B.C. and Ptolemy I having died in $279 / 278$ B.C., it follows that the founding of the Alexandrian Museion must have taken place between 307 and $279 / 278$ B.C.

In accordance with the Peripatos, the Museion housed a scientific community, very much like the colleges of the British universities (of former times). But whereas the Peripatos was an independent scientific community, the Museion depended strongly on the Ptolemaic kings, who appointed the scholars and paid them. It is interesting to find famous names like Euclid, Eratosthenes or Archimedes - but no philosophers - among the Alexandrian scholars. ${ }^{5}$ While we do not know whether the scholars had to teach or only do research, we do know positively that there were problems involved in their living together. Timon of Phlius, an author of the 3 rd century в.c., has recorded the following verse of a satirical poem: 'Many are fed in populous Egypt, book-stakes [a play on the word for 'papyrus stalks'], quarrelling without end in the Muses' basket. ${ }^{6}$

Because there are no archacological traces left of the Museion, we are forced to rely on the classical written sources for information on the edifices of the Museion. The main source is the Greek geographer Strabo, who paid a visit to Alexandria in the second half of the first century B.C. According to his description, the Museion was part of the Brucheion, which was situated in the northeastern district of the city adjoining the harbour. When he visited the Museion, he found a peripatos (a lobby), an exedra (a columned hall), where the scholars could hold their discussions, and an oikos (a dining hall). He does not mention a library as a separate building. ${ }^{7}$ This is a very important point, which I shall come back to later.

Even if we do not know much about the buildings of the Museion, we have some details of how the library worked. The Greek physician and writer Galen (2nd century 
A.D.), for instance, reports on how the Alexandrian kings acquired the books for their library. One method was to charge traders around the Mediterranean with buying books wherever they could obtain them; the other was to confiscate the books found on the ships moored in the Alexandrian harbour. Galen tells us also that the Museion made copies of the confiscated books and gave the owners back only the copies, keeping the originals and entering them in a catalogue entitled 'From the ships'. ${ }^{8}$ We know from other sources that there must also have been catalogues listing the original owners of the copies and others listing the place where a copy was bought or written. ${ }^{9}$

The most famous of those catalogues were, of course, the Pinakes of Kallimachos (pinakes meaning writing tablets), and Kallimachos, the great Alexandrian poet and philologist, being the author of the catalogue. We know that the Pinakes, covering Izo papyrus scrolls, entered the works collected in the Museion by literary genre, if we construe 'literary genre' very broadly: there was, for instance, a section entitled nomoi, i.e. 'laws' or 'customs', and there must have been other sections devoted to tragedies and poems, and even to the art of baking. Within each section the books were entered according to the author's name, but the alphabetical order was somehow odd: Kallimachos did not use complete alphabetical order, but followed only the first letter of the name. Each entry contained a short biography of the author, followed by a list of his works and ending with commentaries by other authors. ${ }^{10}$

The purpose of the catalogue was not to serve as a library catalogue but as a tool for bibliographical and philological work. Such a means was highly desirable, because papyrus scrolls had no title page and determining the author and the specific work contained on a scroll was therefore an enormous task. The fact that almost all medical texts were attributed to an author named Hippocrates, while many poems - and not only the Iliad and the Odyssey — were attributed to an author named Homer demonstrates how difficult the necessary bibliographical work was. The Alexandrian philologists, who were deeply interested in the problem of authorship, tried to solve this problem by meticulous textual studies; their studies resulted in the first critical editions and bibliographical lists of works, the most famous of which was the Pinakes of Kallimachos. ${ }^{11}$

This aspect is very important in order to judge the scholarly work done in the Museion. The Alexandrian philologists were devoted to written records, but their devotion included the willingness to correct and improve texts if necessary, the standard for necessity being not the untouchable corpus of tradition but human reason. This is quite different from the Oriental approach to their textual tradition. The fact that the key texts were religious in the Orient meant that changes or corrections were precluded, while in the Greek cultural sphere the key texts were attributed to secular authors rather than to God. ${ }^{12}$ The Greeks were thus able to develop the science of philology; its birthplace was the Museion in Alexandria. And because each science needs its specific tools, we should consider the library of the Museion and the Pinakes as the main tools of Alexandrian philology. Since Alexandria, the words 'philology' and 'library' have come to mean the joint work of securing our material canon of written records. ${ }^{13}$

\section{The stories}

If we know so few facts about the Museion and its library, why, then, did it become the most famous of all the ancient libraries? The answer is that the library appears in 
so many important stories that it is not the meagre facts but the stories that are responsible for the significance of the Museion. Three examples will serve to illustrate this.

\section{The great texts}

As I mentioned above, Alexandrian philology was devoted to the written records, and that meant for the most part to the works of Homer. We have reliable evidence that the Alexandrian philologist Zenodotus was the first to correct the manuscripts of the Homeric works and that he divided the Odyssey and the Iliad into 24 cantos each and took the view that the Iliad and the Odyssey were the only genuine works by Homer. ${ }^{14}$ To do this work, he must have relied on the library, which contained many different editions of the works of Homer. We can only estimate how many editions Zenodotus was able to use - some scholars believe the Museion held between twenty and thirty editions of the works of Homer ${ }^{15}$ - but the names of some editions have been preserved: some were called 'from the towns', while one was named ek museiou, 'from the Museion', ${ }^{16}$ indicating that this edition was produced by the scholars of the Museion.

While the sources reporting the philologists' work on the Homeric texts are reliable, this does not apply to scholars of the Museion. the works of Aristotle. According to Aristotle's last will as reported by Diogenes Laertius, ${ }^{17}$ his library was given to his successor Theophrastus, who wanted to give the library, in turn enriched by his own works, to his successor Neleus. But Neleus was not elected head of the Peripatos and therefore went back to his home town, Skepsis, taking with him all the books in the library of Aristotle and Theophrastus. And at this point things become interesting, because one line of the classical sources says Ptolemy II bought the works of Aristotle and Theophrastus for the Museion from Neleus' heirs, while another line states - I am admittedly omitting several steps - that the library was taken to Rome, where Andronicus of Rhodes used it to produce an edition of Aristotle's works. ${ }^{18}$

Since the library obviously cannot be in two places at the same time, many scholars have evaluated the sources in an attempt to find clear evidence for one of the two possibilities. But instead of squeezing the sources in search of absolute truth, we should be aware that both lines are telling a political story reflecting the basic myths of western civilization: Rome is a symbol of power and at the same time one of the main pillars of our own culture, while Alexandria symbolizes deep erudition and, at the same time, oriental luxury and decadence. Both traditions, each of which is included in our own tradition, therefore seek to claim Aristotle's library, because it is through this library that they partake of one of the sources of our western civilization.

If Greek philosophy is one such source, the other is the Bible. It does not come as a surprise that a classical source, the so-called 'letter of Aristeas', relates that Ptolemy II wrote a letter to the high priest in Jerusalem, requesting seventy-two wise men to translate the Jewish nomos, the 'law', in Alexandria. When the wise men arrived in Alexandria, they needed only seventy-two days for the translation, the result being the Septuagint. ${ }^{19}$ Unfortunately the 'letter of Aristeas' is a fake, but a very interesting one. ${ }^{20}$

If the letter to a certain extent reflected historical facts, it could be evidence that the Alexandrian kings had an interest in non-Greek texts. But if the letter were a complete fake, it might reflect the Alexandrian Jewish community's interest in demonstrating that their religion was compatible with the Hellenistic life-style. While this is open to 
speculation, we do know for certain that the Old Testament was translated into Greek in Alexandria, whether this translation was produced in the Museion or not.

But what makes the story even more interesting is the fact that the Talmud refers to it. In an addition to the Megillath Ta'anith, for instance, we read: 'On the eighth [viz. seventh] of Tebet [December/January] the law was written in Greek in the days of King Tolmai [Ptolemy] and darkness came upon the world for three days. ${ }^{, 21}$ This means that, from a Jewish perspective, Alexandrian philology is simply a cosmic catastrophe. But why? There are two possibilities: either it is a catastrophe because the Greek translation of the 'law' expropriates the former Jewish owners of the Old Testament, or it is a catastrophe because the Greek translation symbolizes the division of the Jewish community into a Hebrew-speaking and a Greek-speaking community and hence the destruction of its former unity. When the Palestinian Talmud states 'Thirteen sections were altered by the wise men for King Ptolemy, ${ }^{22}$ this implies that the Greek translation is not the original text: the original divine nomos is still the exclusive property of the Hebrew-speaking Jews in Palestine. ${ }^{23}$

\section{The total of books}

The total of books collected in the library of the Museion is even more open to guesswork. Johannes Tzetzes, a Byzantine scholar of the twelfth century, states that the Museion had collected 400,000 bibloi symmigeis [mixed books] and 90,000 bibloi amigeis [unmixed books]. ${ }^{24}$ Gellius, who died about A.D. I30, reports that in Caesar's time the library in the Museion held about 700,000 scrolls, ${ }^{25}$ whereas, in his famous account of Caesar's political and military problems in Alexandria, Seneca refers to a total of 40,000 scrolls having been burnt. ${ }^{26}$

The confusion is not only heightened by discrepancies between the figures in some of the ancient manuscripts but also by our inability to pinpoint the exact meaning of the Greek words biblio symmigeis or amigeis. ${ }^{27}$ But the main confusion may be caused by the fact that Johannes Tzetzes, a generally reliable scholar, bases his section about the Alexandrian library on the 'letter of Aristeas" ${ }^{28}$, which we know is a fake. Some scholars have therefore capitulated and stated that the figures merely indicate a 'vast number' of scrolls.

But I think we can shed some light on this question by asking how many modern books 500,000 papyrus scrolls would be. This is easy to calculate: the 24 cantos of the Homeric Odyssey required 24 papyrus scrolls, and today those 24 cantos can be printed in a single small volume. If we divide the figure of 500,000 scrolls by 24 , this comes out to be slightly more than 20,000 modern books. ${ }^{29}$ It thus seems very implausible that the library held only 40,000 scrolls; that would represent only about 1700 modern books, which would not suffice to make a library famous. The megalê bibliothekê with its 500,000 papyrus scrolls was therefore much smaller than one might have imagined.

\section{The burning of the Library}

These problems are exacerbated when we seek to determine whether the library really was burnt under Caesar. The traditional story is as follows: in 48 B.C. Caesar came to 
Alexandria in pursuit of Pompeius, his adversary in the Civil War. When he arrived, Pompeius had already been killed, but Caesar now had to intervene in the conflict between the Ptolemeic heirs to the throne, in which he took a stand for Cleopatra. In 47 B.C., his small troops of about 3200 men were encircled by 20,000 Egyptian soldiers, and he was forced to retreat to the harbour, where he burnt the Egyptian fleet to prevent the Egyptian forces from being supplied. But unfortunately the fire spread from the ships to the docks, and from the docks to the buildings of the Brucheion, and one of the buildings that burnt down was the Museion.

We can only believe in this story if we can ignore the fact that neither Caesar nor Cicero in their writings nor any other author of the decades B.C. reports that the Museion and/or its library were burnt. And even Seneca, who seems to be a reliable source with respect to the burning of the library, only refers to books being burnt 'in Alexandria' (Latin locative: Alexandriae); he does not say that the books in the library of the Museion were burnt. ${ }^{30}$ And, finally, Strabo, who paid a visit to Alexandria shortly after the battles, does not refer to the destruction of that institution or its library in his description.

The answer to the mystery is contained in a text by Cassius Dio, who writes that during the battles some apothékai, i.e. warehouses, caught fire. ${ }^{31}$ It seems very plausible that these warehouses were part of the docks, and therefore it is very likely that the books burnt were stored in warehouses prior to being exported. ${ }^{32}$

\section{The endless Universal Library}

Aside from all these stories, it is evident that we have very little exact knowledge of the Alexandrian library. The library was evidently not in a separate building but simply consisted of the books stored in the exedra of the Museion. ${ }^{33}$ And it seems likely that, rather than being a universal library in the modern sense, the library served as the main tool for the academic research conducted at the Museion. This research was deeply related to Greek culture as it had been implanted in Egypt. Whether the Greek context was transcended in some cases is open to question, as is the story of the translation of the Septuagint in the Museion.

Once we stop this little game of facts and stories or histories, it becomes obvious that it is almost impossible to separate facts from stories/histories. Rather than being a deficiency, this is in itself a remarkable and significant fact. But what are the implications of the fact that the overwhelming fame of the Alexandrian library derives from the host of stories/histories surrounding the institution? First, our interpretation of what is or was 'real' depends on how texts are interpreted. Secondly, such interpretations are based on the invention of a science of texts more than 2000 years ago by some Greeks in the Museion in Alexandria, which made it possible to correct and improve the written record. Ever since, we have all more or less been Alexandrian philologists, if this represents the unity of philology and history.

The symbol of this unity is the great Alexandrian library. But its greatness is only

one side of the coin, the other being the great catastrophe: the burning of the library. ${ }^{34}$ While we know that this catastrophe (probably) never took place, the possibility of such a catastrophe has been preserved in a long succession of texts originating in the Museion. This implies that the story of the annihilation of the library cannot itself derive from 
this stream of texts. Whatever our view of history and of the fate of the Alexandrian library, we must be conscious that all these views are rooted in a tradition that relates to libraries and that originates in Alexandria. It is within this tradition that we are undeniably and firmly placed.

${ }^{1}$ Daniel Gore (cd.), Farewell to Alexandria: solutions to space, growth, and performance problems of libraries (Westport, Conn.: Greenwood, 1976).

2 For a description of ancient Alexandria and its quarters sce 'Alexandreia' in: Gcorg Wissowa (ed.), Paulys Realencyclopädie der classischen Altertumstvissenschaft, pt. I (Stuttgart: Druckmäller, 1893), cols. 1376-88.

${ }^{3}$ Cf. 'Bibliotheken' in: Wissowa, pt. 5 (Stuttgart: Metaler, I897), cols. 405-24, here col. 409 and ff; cf. also Carl Wendel and Willi Göber, 'Das griechisch-römische Altertum', in: Georg Ley (ed.), Handbuch der Bibliothekswissenschaft vol. $3 / 1$ (Wiesbaden: Harrassowitz, 1955) pp. $51-145$, here pp. $63-82$. The best modern history of the Alexandrian library is Luciano Canfora, The vanished library: a wonder of the ancient world (London: Vintage, I991). For a brief survey of the actual discussion, see: Uwe Jochum, Kleine Bibliotheksgeschichte (Stuttgart: Reclam, 1993) pp. 24-37.

${ }^{4}$ For the names of the Alcxandrian library sec: Athenaeus, The Deipnosophists, with an English translation by Charles Burton Gulick vol. 1 (London: Hcinemann, 1963), section V.203c; Moses Hadas (ed.), Aristeas to Philocrates (Letter of Aristeas) (New York: Ktav, J973), chap. 9; Bernadotte Perrin (ed.), Plutarch's Lives, vol. 7 (London: Heinemann, T958) section Xuıx; C. G. Kühn (ed.), Clandii Galeni opera omnia, vol. 17, pt. 1 (Hildesheim: Olms, 1965) p. 606.

5 Rudolf Blum, Kallimachos und die Literaturverzeichung bei den Griechen: Untersuchungen zur Geschichte der Biobibliographie (Frankfurt am Main: Buchhändler-Vereinigung, 1977), col. 138, translated into English as Kallimachos: the Alexandrian Library and the origins of bibliograpby (Madison, Wis.: Univ. of Wisconsin P., 1991); Rudolf Pfeiffer, Geschichte der Klassischen Philologie: von den Anfägen bis zum Ende des Hellenismus 2 nd edn. (Munich: Beck, 1978), p. 125 \& ff., translated into English as History of classical scholarship: from the beginnings to the end of the Hellnistic age (Oxford: Clarendon, 1978).

'Athenacus, section I.22d; Gulick translates as: 'Many there be that batten in populous Egypt, well-propped pedants who quarrel without end in the Muses' bird-cage.'

7 Horace Leonard Jones (cd.), The geography of Strabo, vol. 8 (Cambridge, Mass.: Harvard University Press, 1959), section 17.1.8.

${ }^{8}$ Galeni opera omnia, vol. 17, pt. I, p. 606.

9 For details sec Blum, col. 30т \& ff.

${ }^{10}$ Blum, col. 22.4 \& ff.

11 Pfeiffer, pp. 11.4 \& ff.; Blum, col. 301 \& $\mathrm{ff}$.

12 Carl Wendel, Die griechisch-römische Buchbeschreibung verglichen mit der des vorderen Orients (Halle: Niemeyer, 1949); see also Uwe Jochum, Die ldole der Bibliothekare (Würzburg: Königshausen \& Neumann, 1995), pp. 89-96.

13 For a discussion of the notion 'canon', see Pfeiffer, p. 255; Jan Assmann, Das kulturelle Gedächtnis: Schrift, Erimnerung und politische Identität in fribhen Hochkulturen (Munich: Beck, 5991) pp. I03 \& ff.; and Jochum, Idole, p. $93 \& \mathrm{ff}$.

14 Pfciffer, p. 148 \& ff.

15 C. Haeberlin, "Einfache" und "Misch-Rollen" in den antiken Bibliotheken', Zeitschrift für Bibliotbekswesen 7 (т890) 1 8 , here p. 5 .

16 Pfeiffer, pp. I22 \& I4T.

17 R. D. Hicks (ed.), Diogenes Lacrtius, Lives of eminent philosophers, vol. I (London: Heinemann, I959), scction V.5I \& ff.

18 For a discussion and an evaluation of the different traditions sce Canfora, part 2, chap. I2.

19 Cf. Aristeas to Philocrates.

20 Sec the introduction to Aristeas to Philocrates by Moses Hadas.

21 Aristeas to Philocrates, p. 83.

22 I used a German translation: Megilla: Schriftrolle, ed. Frowald G. Hüttenmeister (Tübingen: Mohr, 1987 ) [translation of the Talmud Yerushalmi, II/ro], section 1.7 Id, 46-55: 'Dreizehn Dinge änderten die Weisen (bei der Ubersetzung der Bibel ins Griechische) für den König Ptolemałus (II. Philadelphus).'

${ }^{23}$ For more information on the Museion and the tradition of texts, see Luciano Canfora, La Bibliothèque d'Alexandrie et l'bistoire des textes (Liège: Cedopal, 1992).

24 'Ioannis Tzetzae in Aristophanem bis bina prooemia peri komodias', in: Georg Kaibel (ed.), Comicorum Graecorum fragmenta vol. T, 1 (Berlin: Weidmann, 5899) pp. 17-33, here p. 19 \& ff.

${ }_{25}$ P. K. Marshall (ed.), Aulus Gellius, A. Gellii Noctes Atticae, vol. 1 (Oxford: Clarendon, r990), section vıı.3. 
26. John W. Basore (ed.), Sencca, Moral essays, vol. 2 (Cambridge, Mass.: Harvard University Press, I958), section $1 \mathrm{X} .5$.

${ }_{27}$ A survey of the different interpretations is to be found in Jochum, Kleine Bibliotheksgeschichte, p. 26, n. 6.

28. Pfeiffer, p. 133.

29 Horst Blanck, Das Buch in der Antike (Munich: Beck, r992) p. I4\%, uses slightly different figures.

${ }^{30}$ Seneca, section ix.5: 'Quadraginta milia librorum Alexandriæ arserunt.'

31 Earnest Cary (ed.), Cassius Dio, Dio's Roman history, vol. 4 (London: Heinemann, 1959), section XLn. 38.2. The Greck text clearly says that apothekas kai tou sitou kai tôn biblôn were burnt. Therefore Cary's translation is a good (or bad) piece of interpretation: 'the storchouses of grain among other buildings were burnt, and also the library'.

${ }^{32}$ Jochum, Kleine Bibliotheksgeschichte, pp. 33 \& ff., discusses the different classical loci and their interpretations.

33 Canfora, chap. $\mathrm{I}_{3} \& \mathrm{ff}$.

34. For more burning libraries, cf. Jochum, Idole, pp. I25 \& $\mathrm{ff}$. 